\title{
Formulation and Evaluation of Fast Dissolving Oral Films of Risperidone
}

\author{
Ajith Reddy C ${ }^{*}$, Uma Sankar $\mathrm{K}^{\oplus}$, Kishore Babu M
}

Department of Pharmaceutics, Krishna Teja Pharmacy College, Chadalawada Nagar, Renigunta Road, Tirupathi-517506, Andhra Pradesh, India

\begin{tabular}{|c|c|}
\hline Article History: & ABSTRACT \\
\hline $\begin{array}{l}\text { Received on: } 10 \text { Dec } 2021 \\
\text { Revised on: } 28 \text { Dec } 2021 \\
\text { Accepted on: } 30 \text { Dec } 2021\end{array}$ & \multirow{3}{*}{$\begin{array}{l}\text { The current research was primarily directed to develop and implement anc } \\
\text { evaluate rapidly disintegrating Risperidone using HPMC E15 and HPMC E5 } \\
\text { The acceptable plasticizer but also its concentration were based on the basi } \\
\text { of flexibility, tensile strength and stickiness of a film. The films are solven } \\
\text { casting process. The thicknesses of the films were in the range of } 0.234 \mathrm{~mm} \text { t } \\
0.271 \mathrm{~mm} \text {. The weights of films have been noticed being in the range of } 83 \mathrm{tc} \\
91 \text {. Folding endurance of films had been noticed being in the scope of } 38 \pm 1 \text { tc } \\
57 \pm 2 \text {. The surface PH of all films have been encountered to really be neutra } \\
\text { since there was no change in color inside the litmus paper. The disintegratior } \\
\text { time of such ready films were all in the scope of } 19 \mathrm{sec} \text { to } 32 \mathrm{sec} \text {. }\end{array}$} \\
\hline Keywords: & \\
\hline $\begin{array}{l}\text { Fast Dissolving, } \\
\text { Oral Films, } \\
\text { Risperidone, } \\
\text { In-vitro Dissolution, } \\
\text { Disintegration }\end{array}$ & \\
\hline
\end{tabular}

${ }^{*}$ Corresponding Author

Name: Ajith Reddy C

Phone: +918500170013

Email: ajithreddy861998@gmail.com

eISSN: 2583-116X

pISSN:

DOI: https://doi.org/10.26452/fjphs.v2i1.168

Production and Hosted by

Pharmasprings.com

(C) $2022 \mid$ All rights reserved.

\section{INTRODUCTION}

Even after of many of advance that have been made in variety delivery mechanism established for administering of varied drugs and via alternate paths such as oral, parenteral, transdermal, nasal, etc., the oral drug delivery is taken into account as one of the most efficient and also the preferred approach of administration [1]. More so than $70 \%$ of medicine can be found available in the market within form of oral drug delivery. Because of this problem roughly $50 \%$ of population mainly paediatric population and elderly individuals generally avoid orally ingested solid oral dosage. Keeping the convenience of administration but also trying to swallow in mind, drug research has resulted in the development of fast dissolving drug delivery [2].
Risperidone is effective for going to treat the positively and negatively symptoms of schizophrenia compared to first generation antipsychotics [3].

\section{MATERIALS}

Risperidone was a gift sample from Pharma train Hyderabad. HPMC E15, HPMC E5, Propylene glycol, Sorbitol, Aspartame, Tween 80, Citric acid and flavouring agent seemed to be actually bought from S.D. Fine chemicals, Mumbai.

\section{METHODOLOGY}

\section{Compatibility Studies}

Sample concentration in KBr must be within the limits of $0.2 \%$ to $1 \%$. The thickness of the pellet is much greater than a liquid film, so sample with low concentration is required. Too high concentration generally leads to difficulties in obtaining clear pellets [4].

\section{Formulation of Risperidone Fast Dissolving Films}

Mouth dissolving film of Risperidone was prepared by solvent casting technique. Solution A was decided to make by solubilising HPMC-E15 polymer in five ml of liquid. Solution B was already decided to make by dissolving Risperidone, Aspartam, Sorbitol $\&$ citric acid in $5 \mathrm{ml}$ of ethanol. The source of ideas ' $\mathrm{A}$ ' 
and 'B' have been combined and incensed for $30 \mathrm{~min}$ and add Propylene glycol and tween 80 and flavouring agent and continue stirring for $10 \mathrm{mins}$ [Table 1]. The solutions company were poured it onto glass petri plate of $9 \mathrm{~cm}$ diameter but were located in the oven at $70^{\circ} \mathrm{C}$ until a wax coated film was created and after that solidified films have been cut into rectangular or circular pieces with $4.0 \mathrm{~cm}^{2}(2.0 \mathrm{~cm} \times 2.0$ $\mathrm{cm}$ ) large surface area. Desired quantity of Risperidone had been $10 \mathrm{mg}$ (dose of drug) per $4.0 \mathrm{~cm}^{2}$ feature films [5].

\section{Morphological Properties}

This measurement device has been quickly checked simply with testing process for physical features of films and assessment of surface by touch or consult [6].

\section{Thickness Uniformity}

All the portions were evaluated for thickness through using calibrated Vernier caliper [7].

\section{Weight Uniformity of Films}

Three films of each formulation trial of $2 \mathrm{~cm}$ size have been taken and decided to weigh independently electronic balance and the average weights were determined by calculating [8].

\section{Folding Endurance}

The Multiple films of each composition trial of $2 \mathrm{~cm}$ length have been captured and concluded to weigh independently electronic weighing balance and the estimate weights were the flexibility of films can also be measured quantitative and qualitative in terms of folding endurance. The one strip of film was cut (approximately $2 * 2 \mathrm{~cm}$ ) and again and again folded at the same position until burst. The number of times the film may be folded at the same position without bursting gave the value of folding endurance [9].

\section{Surface pH}

The surface $\mathrm{pH}$ was noted by trying to bring $\mathrm{pH}$ paper closer to the surface of the films and permitting it to equilibrium for $1 \mathrm{~min}$ [5].

\section{In vitro Disintegration Test}

In vitro disintegration rate is decided visibly in a glass baking dish $25 \mathrm{ml}$ water to roiling each $10 \mathrm{sec}$. The disintegration time is indeed the time whenever the film begins to break or disintegrates [10].

\section{In vitro Dissolution Studies}

The dissolution medium consists entirely of 900 $\mathrm{mL} 6.8 \mathrm{pH}$ phosphate-buffer solution, retained at $37 \pm 0.5^{\circ} \mathrm{C}$ and agitated at $50 \mathrm{rpm}$. One film has been used in each test. Samples of dissolution medium (5ml) have been withdrawn with syringe equipped with pre-filter at known intervals and release of drug was evaluated UV-spectrophotometer at $280 \mathrm{~nm}$. The quantity forced to withdrawn at every intervals was supplemented with newly quantity of dissolution medium. Cumulative percentage drug discharge of Risperidone was calculated and obtained by plotting on that time [11].

\section{Mathematical Modeling for Drug Release Profile}

The data acquired from the in vitro dissolution tests obtain the kinetic track record analysis [4].

Zero-order kinetics: $Q_{t}=Q_{o}+K_{o} t$

First-order kinetics: $Q_{t}=\log Q_{o}+K_{1} t / 2.303$

\section{Stability Studies}

The stability study had been performed as per ICH guidelines for such period with one month at various accelerated temperature [12] and humidity conditions of $40^{\circ} \mathrm{C} \pm 2^{\circ} \mathrm{C} / 75 \% \pm 5 \% \mathrm{RH}$.

\section{RESULTS AND DISCUSSION}

\section{FT-IR Studies}

From drug excipient compatibility trend analysis, we referred to the omission of conversations among both pure drug and excipients [Figure 1].

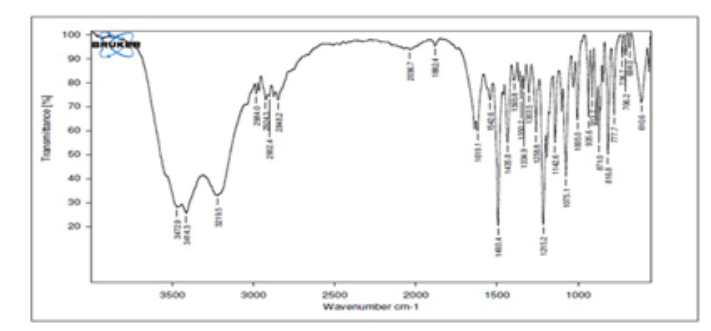

FTIR Spectra of Risperidone

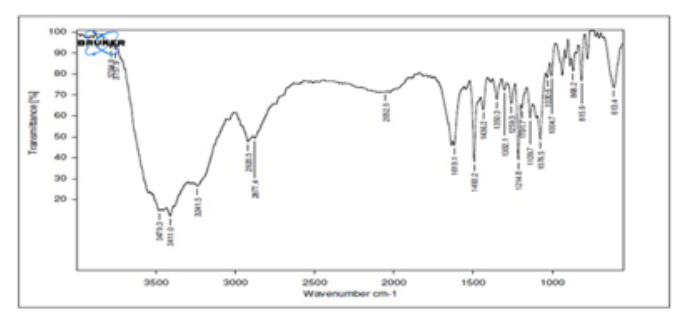

FTIR Spectra of Mixture of Compounds

\section{Figure 1: FTIR Spectrum of Drug and Mixture of Compounds}

The inspection by condition monitoring of films and so by feel or touch, it explains that films are having surface texture and they are elegant. The thicknesses of the films were in the range of $0.234 \mathrm{~mm}$ to $0.271 \mathrm{~mm}$. The weights of films have been noticed being in the range of 83 to 91 . Folding endurance of films had been noticed being in the scope of $38 \pm 1$ to 
Table 1: Formulation of Risperidone Fast Dissolving Films

\begin{tabular}{|c|c|c|c|c|c|c|c|c|c|}
\hline Ingredients & F1 & F2 & F3 & F4 & F5 & F6 & F7 & F8 & F9 \\
\hline Risperidone & 0.5 & 0.5 & 0.5 & 0.5 & 0.5 & 0.5 & 0.5 & 0.5 & 0.5 \\
\hline HPMC E15 & 25 & 30 & 35 & 40 & 45 & 50 & 10 & 20 & 30 \\
\hline HPMC E5 & - & - & - & - & - & - & 30 & 20 & 10 \\
\hline Propylene glycol & 10 & 10 & 10 & 10 & 10 & 10 & 10 & 10 & 10 \\
\hline Sorbitol & 34 & 29 & 24 & 19 & 14 & 9 & 19 & 19 & 19 \\
\hline Aspartame & 5 & 5 & 5 & 5 & 5 & 5 & 5 & 5 & 5 \\
\hline Tween 80 & 5 & 5 & 5 & 5 & 5 & 5 & 5 & 5 & 5 \\
\hline $\begin{array}{l}\text { Saliva stimulating } \\
\text { agent (citric acid) }\end{array}$ & 5 & 5 & 5 & 5 & 5 & 5 & 5 & 5 & 5 \\
\hline Flavouring agent & 0.5 & 0.5 & 0.5 & 0.5 & 0.5 & 0.5 & 0.5 & 0.5 & 0.5 \\
\hline Total wt. (mg) & 85 & 85 & 85 & 85 & 85 & 85 & 85 & 85 & 85 \\
\hline
\end{tabular}

Table 2: Evaluation Parameters of Risperidone FDF

\begin{tabular}{cccccc}
\hline $\begin{array}{c}\text { Formulation } \\
\text { code }\end{array}$ & $\begin{array}{c}\text { Thickness } \\
(\mathrm{mm})\end{array}$ & $\begin{array}{c}\text { Weight } \\
\text { variation }\end{array}$ & $\begin{array}{c}\text { Folding } \\
\text { endurance }\end{array}$ & \% Assay & $\begin{array}{c}\text { Disintegration } \\
\text { time (sec) }\end{array}$ \\
\hline F1 & 0.234 & 87 & 42 & 99.13 & 19 \\
F2 & 0.271 & 91 & 51 & 98.79 & 24 \\
F3 & 0.263 & 83 & 38 & 99.82 & 21 \\
F4 & 0.247 & 85 & 57 & 100.17 & 27 \\
F5 & 0.257 & 87 & 54 & 99.48 & 32 \\
F6 & 0.234 & 90 & 49 & 101.07 & 28 \\
F7 & 0.238 & 86 & 45 & 100.29 & 26 \\
F8 & 0.265 & 91 & 39 & 99.37 & 23 \\
F9 & 0.268 & 87 & 48 & 100.53 & 27 \\
\hline
\end{tabular}

Table 3: In-vitro drug release data of formulation F1 to F9

\begin{tabular}{cccccccccc}
\hline Time (min) & & \multicolumn{1}{c}{ \% Drug Release } \\
& F1 & F2 & F3 & F4 & F5 & F6 & F7 & F8 & F9 \\
\hline 0 & 0 & 0 & 0 & 0 & 0 & 0 & 0 & 0 & 0 \\
3 & 24 & 23 & 35 & 27 & 26 & 24 & 39 & 63 & 65 \\
6 & 31 & 35 & 46 & 35 & 39 & 31 & 61 & 76 & 86 \\
9 & 38 & 41 & 58 & 49 & 51 & 53 & 83 & 83 & 95 \\
12 & 53 & 50 & 72 & 63 & 68 & 68 & 97 & 95 & 100 \\
15 & 64 & 59 & 79 & 75 & 80 & 81 & 98 & 99 & - \\
18 & 71 & 70 & 85 & 86 & 89 & 95 & 98 & - & - \\
21 & 78 & 82 & 92 & 97 & 97 & 99 & - & - & - \\
24 & 82 & 89 & 99 & 99 & 100 & - & - & - & - \\
27 & 85 & 94 & - & - & - & - & - & - & - \\
30 & 91 & 97 & - & - & - & - & - & - & - \\
\hline
\end{tabular}

Table 4: $\mathbf{r}^{2}$ Values for Best Formulation F9

\begin{tabular}{ccc}
\hline Formulation code & Zero order & First order \\
\hline F9 & 0.789 & 0.999 \\
\hline
\end{tabular}


Table 5: In-vitro Release Profile of F9 Formulation Stability Studies

\begin{tabular}{ccc}
\hline Time & Initial & 1 Month \\
\hline 0 & 0 & 0 \\
3 & 65 & 64 \\
6 & 86 & 87 \\
9 & 95 & 95 \\
12 & 100 & 100 \\
\hline
\end{tabular}

$57 \pm 2$. The surface PH of all films has been encountered got really be neutral since there was no change in colour inside the litmus paper [Table 2]. The disintegration time of such ready films were all in the scope of 19 sec to $32 \mathrm{sec}$.

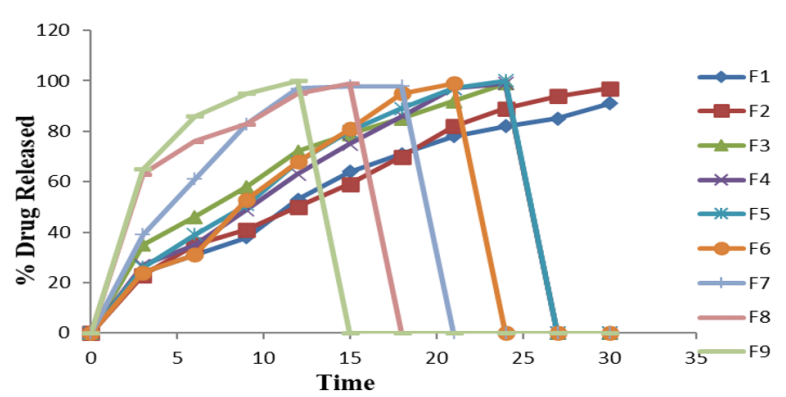

Figure 2: Dissolution Profile for F1 to F9 Formulations

\section{Stability Studies}

Selected formulation F9 was strip packed and stored at $40^{\circ} \mathrm{C} \pm 2{ }^{\circ} \mathrm{C} / 75 \% \pm 5 \% \mathrm{RH}$ [Table 3, Table 4] or indeed a duration of 1 month [Table 5]. Samples were evaluated now since storage for 1 month as well as assessed [Figure 2, Figure 3].

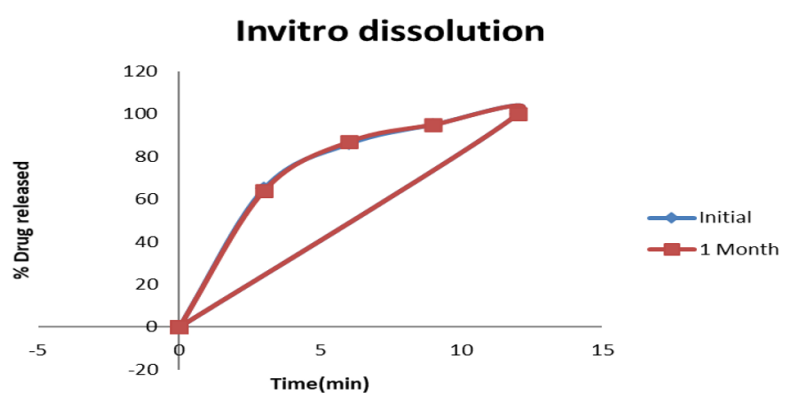

Figure 3: In-vitro Release Profile of F9 During Stability Studies

\section{CONCLUSION}

Risperidone orally disintegrating films were successfully prepared with HPMC E15CPS and HPMC E15 \& HPMC E5 combination. The disintegration time of the prepared films were in the range of $21 \mathrm{sec}$ to $32 \mathrm{sec}$. The $\mathrm{F} 9$ formulation in vitro disintegration time was below of $27 \mathrm{sec}$. It was concluded that formulations F9 were found to be satisfactory batch and were optimized for the desirable properties.

\section{ACKNOWLEDGEMENT}

I would like to thanks to Dr. M. Kishore Babu Garu, Principal of Krishna Teja Pharmacy College, Chadalawada Nagar, Renigunta Road, Tirupathi517506, Andhra Pradesh, India.

\section{Funding Support}

The authors declare that they have no funding support for this study.

\section{Conflict of Interest}

The authors declare that there is no conflict of interest.

\section{REFERENCES}

[1] Parul Saini, Anoop Kumar, Pankaj Kumar Sharma, and Sharad Visht. Fast Disintegrating Oral Films: A Recent Trend of Drug Delivery. International Journal of Drug Development and Research, 4(4):80-94, 2012.

[2] Rajni Bala, Pravin Pawar, Sushil Khanna, and Sandeep Arora. Orally Dissolving Strips: A New Approach to Oral Drug Delivery System. International Journal of Pharmaceutical Investigation, 3(2):67-76, 2013.

[3] A Arya, A Chandra, V Sharma, and K Pathak. Fast dissolving oral films: an innovative drug delivery system and dosage form. International Journal ofChemTech Research, 2(1):576583, 2010.

[4] Smita V. Pawar and M. S. Junagade. Formulation and Evaluation of Mouth Dissolving Film of Risperidone. International Journal of PharmTech Research, 8(6):218-230, 2015.

[5] R. C. Mashru, V. B. Sutariya, M. G. Sankalia, and P. P. Parikh. Development and Evaluation of Fast-Dissolving Film of Salbutamol Sulphate. Drug Development and Industrial Pharmacy, 31(1):25-34, 2005.

[6] Francesco Cilurzo, Irma E. Cupone, Paola 
Minghetti, Francesca Selmin, and Luisa Montanari. Fast dissolving films made of maltodextrins. European Journal of Pharmaceutics and Biopharmaceutics, 70(3):895-900, 2008.

[7] S Kalyan and M Bansal. Recent trends in the development of oral dissolving film. International Journal of PharmTech Research, 4(2):725-733, 2012.

[8] Misao Nishimura, Katsuhiko Matsuura, Tadao Tsukioka, Hirotaka Yamashita, Naoki Inagaki, Tadashi Sugiyama, and Yoshinori Itoh. In vitro and in vivo characteristics of prochlorperazine oral disintegrating film. International Journal of Pharmaceutics, 368(1-2):98-102, 2009.

[9] Hao Zhang, Jie Zhang, and James B. Streisand. Oral Mucosal Drug Delivery. Clinical pharmacokinetics, 41(9):661-680, 2002.

[10] Zainab E Jassim, Mais F Mohammed, and Zainab Ahmed Sadeq. Formulation and Evaluation of Fast Dissolving Film of Lornoxicam. Asian Journal of Pharmaceutical and Clinical Research, 11(9):217-223, 2018.

[11] Poonam A. Padamwar and Poonam P. Phasate. Formulation and evaluation of fast dissolving oral film of bisoprololfumarate. International Journal of Pharma Sciences and Research, 6(1):135-142, 2015.

[12] Ashish Jain, Harish C Ahirwar, Shivam Tayal, and Pradeep K. Mohanty. Fast dissolving oral films: A tabular update. Journal of Drug Delivery and Therapeutics, 8(4):10-19, 2018.

Copyright: This is an open access article distributed under the terms of the Creative Commons Attribution-NonCommercialShareAlike 4.0 License, which allows others to remix, tweak, and build upon the work non-commercially, as long as the author is credited and the new creations are licensed under the identical terms.

Cite this article: Ajith Reddy C, Uma Sankar K, Kishore Babu M. Formulation and Evaluation of Fast Dissolving Oral Films of Risperidone. Future J. Pharm. Health. Sci. 2022; 2(1): 35-39.

Pharma Springs

(C) 2022 Pharma Springs Publication. 